\title{
Night air conditioning of buildings by external air ventilation
}

\author{
Climatización nocturna de edificaciones por ventilación de aire exterior \\ Climatização noturna de edificações por ventilação de ar exterior
}

Fecha de recepción: 8 de enero de 2018

Debrayan Bravo-Hidalgo*

Fecha de aprobación: 16 de abril de 2018

\section{Abstract}

Buildings contain the environment in which almost all human activities take place, and therefore, nowadays, they represent a great sink of energy. Establishing thermal comfort conditions within these buildings is responsible for a large portion of their energy demand. This paper aims at providing a theoretical framework of the performance and the trends in research and implementation of night air conditioning by outside air ventilation. The bibliographic search was conducted in the academic directory Scopus, and the information extracted was processed in the VOSviewer software, through which text mining, map of terms and networks of investigative action were carried out. The literature showed that direct ventilation has a more significant cooling potential in regions characterized by a high difference between day and night air temperatures. The effectiveness of night cooling and the reliable prediction of thermal behavior are strongly related to the model adopted for the convection algorithm. A reliable prediction of heat transfer by convection requires an approach based on computational simulations of fluid dynamics, which are much more demanding in terms of computational power, compared to simulations of the variation of energy flows as a function of time. Most studies showed that the position of the thermal mass is not significant, while the amount of ventilation air is of great importance. In particular, the energy demand for cooling a building decreases sharply if the air flow rates increase.

Keywords: efficiency; energy strategy; thermal comfort; text mining.

\section{Resumen}

Los edificios contienen el entorno en el cual se desarrollan casi la totalidad de las actividades humanas; por ende, estas construcciones representan hoy un gran sumidero de energía. El establecimiento de las condiciones de confort térmico dentro de estos inmuebles es responsable de gran parte de su demanda energética. Ofrecer un marco teórico del desempeño y las tendencias en las investigaciones e implementaciones de la climatización nocturna de edificaciones por ventilación de aire exterior es el objetivo de este trabajo. La contribución se sostiene en una revisión bibliográfica realizada en el directorio académico Scopus. La información extraída de dicho catálogo fue procesada en el software VOSviewer, mediante el cual se realizó la minería de texto, el mapa de términos y las redes de acción investigativa. La ventilación directa tiene un potencial de enfriamiento más significativo en regiones que se caracterizan por una elevada diferencia entre el valor de la temperatura del aire en el día y el de la noche. La efectividad del enfriamiento nocturno y la predicción confiable del comportamiento térmico están fuertemente relacionadas con el modelo adoptado para el algoritmo de convección. Una predicción fiable de la transferencia de calor por convección requiere un enfoque basado en el uso de simulaciones computacionales de

* M. Sc. Universidad San Francisco de Quito (Quito, Ecuador). dbravo@rmlconsultores.com. ORCID: 0000-0003-0428-2263. 
dinámica de fluidos, que son mucho más demandantes desde el punto de vista computacional, frente a simulaciones de variaciones de flujos de energía en función del tiempo. En la mayoría de las investigaciones la posición de la masa térmica es poco significativa, mientras que se le da mayor importancia a la cantidad de aire de ventilación. En particular, la demanda de energía para la refrigeración del edificio disminuye fuertemente si las tasas de flujo de aire aumentan.

Palabras clave: confort térmico; eficiencia; estrategia energética; minería de texto.

\section{Resumo}

Os edifícios contêm o ambiente no qual se desenvolvem quase a totalidade das atividades humanas; consequentemente, estas construções representam hoje um grande sumidouro de energia. $\mathrm{O}$ estabelecimento das condições de conforto térmico dentro destes imóveis é responsável de grande parte de sua demanda energética. Oferecer um marco teórico do desempenho e das tendências nas pesquisas e implementações da climatização noturna de edificações por ventilação de ar exterior é o objetivo deste trabalho. A contribuição sustém-se em uma revisão bibliográfica realizada no diretório acadêmico Scopus. A informação extraída deste catálogo foi processada no software VOSviewer, mediante o qual realizou-se a mineração de texto, o mapa de termos e as redes de ação de pesquisa. A ventilação direta tem um potencial de esfriamento mais significativo em regiões que se caracterizam por uma elevada diferença entre o valor da temperatura do ar de dia e de noite. A efetividade do esfriamento noturno e a predição confiável do comportamento térmico estão fortemente relacionadas com o modelo adotado para o algoritmo de convecção. Uma predição fiável da transferência de calor por convecção requer um enfoque baseado no uso de simulações computacionais de dinâmica de fluídos, que são muito mais demandantes desde o ponto de vista computacional, frente a simulações de variações de fluxos de energia em função do tempo. Na maioria das pesquisas a posição da massa térmica é pouco significativa, enquanto que é dada maior importância à quantidade de ar de ventilação. Em particular, a demanda de energia para a refrigeração do edifício diminui fortemente se as taxas de fluxo de ar aumentam.

Palavras chave: conforto térmico; eficiência; estratégia energética; mineração de texto.

\section{Para citar este artículo:}

D. Bravo-Hidalgo, "Night air conditioning of buildings by external air ventilation," Revista Facultad de Ingeniería, vol. 27 (48), pp. 35-47, may. 2018. 


\section{INTRODUCTION}

Air conditioning or air handling processes aimed at providing thermal comfort to people performing various activities in a space defined by buildings is called indoor air conditioning [1,2]. Given the growing world population and the standard of living of modern society, increasing the number of buildings is essential because they contain the environment in which almost all human activities take place. Establishing thermal comfort conditions within these buildings demands a lot of energy, and therefore, nowadays, these constructions represent a great sink of energy [3]. In consequence, researchers, engineers and architects study and implement alternatives to save and optimize energy in cooling off buildings $[4,5]$.

Horas nocturnas.

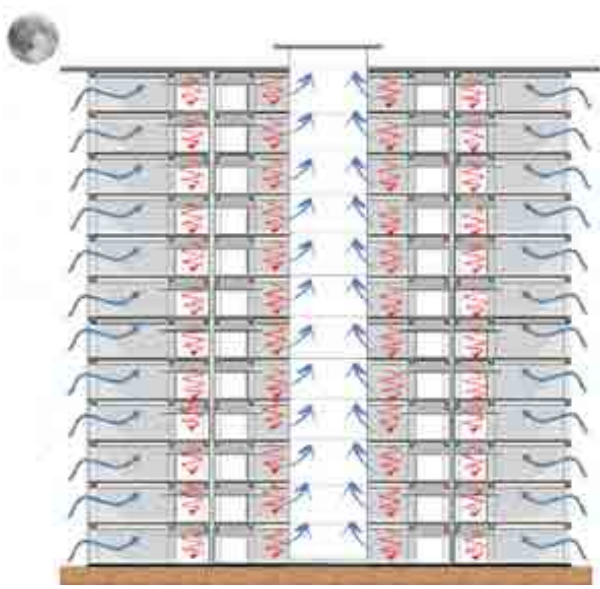

Night ventilation is a bioclimatic strategy that allows the passive cooling of buildings decreasing the energy demand due to air conditioning. Using outside air to cool off rooms at night is a millennial process. Currently, this process is combined with modern and complex processes of active air conditioning of interior spaces (Fig. 1). Given the cooling potential of nocturnal ventilation, two effects are considered based on the observation of the physical phenomenon: First, the direct convective cooling due to the fresh outdoor air that improves the thermal conditions of the building's interior environment and its occupants. And second, the heat exchange between the supplied external air and the interior surfaces of the building envelope, which discharge the thermal mass of the building by the effect of sensible heat removal [6-8].

Fig. 1. Effects of night ventilation.

During the day, the solar radiation and the temperature of the outside air raise the temperature inside the building, increasing the load of the thermal mass. In consequence, both passive and active climate strategies are needed to maintain the thermal comfort inside. Through the night, the fresh air, introduced from outside both convectionally and mechanically, cool the building off by extracting heat from its thermal mass. This process can promote comfort even in the first hours of the day, due to the thermal inertia and the temperature gradient between the inside and the outside.

In regions as distant as the Mediterranean and the Caribbean, differences in outside air temperatures, between day and night, favor the relevance and effectiveness of cooling through night ventilation.
Currently, this energy strategy is applied either by natural ventilation or convection or by forced or mechanical ventilation $[1,9,10]$. Certainly, the effectiveness of wind currents and their psychrometric characteristics, to eliminate the thermal load of buildings, cannot be established simply according to geographical position, because erroneous assumptions can lead to incorrect designs resulting in energy disadvantages of the installation $[11,12]$.

This article aims at providing a theoretical framework of the performance and the trends in the research and implementation of night air cooling of buildings by external air ventilation. 


\section{Methodology}

Scientific contributions, published between 1982 and February 2018, were searched in the academic catalogue Scopus. The search criteria was the presence of the terms "Natural and mechanical night ventilation" either in the title, the summary or the keywords. The search yielded 58 scientific reports and 6,482 patents related to this energy strategy. Within Scopus, the major difference between the registered patents and the scientific reports is that the former show a clearer inclination towards the practice of this climate control. The resulting data were extracted in CSV format and processed in the VOSviewer bibliometric analysis software, which creates, visualizes and explores bibliometric maps of scientific productivity in the various fields.

The information of the detected contributions contained:
a) Title
b) Keywords
c) Author
d) Year

e) Author's afiliations

f) Author's nationality

h) Appointment index

VOSviewer was used for text mining and data analysis of bibliometric networks and collaborative relationships between nations and authors. In addition, it was used to obtain the relation of coincidence between scientific terms under the search criteria previously exposed.

Limitations of the investigation: In this article, we only included investigations that have been cited at least twice.

\section{RESULTS}

The search in Scopus yielded 58 scientific contributions published since 1982 that complied with the search criteria. Figure 2 shows the yearly distribution of the found contributions, but only since 2000 because the number of publications between 1982 and 2000 was low and its distribution irregular. The results showed that in the past 17 years the interest in researching night ventilation has increased (Fig. 2).

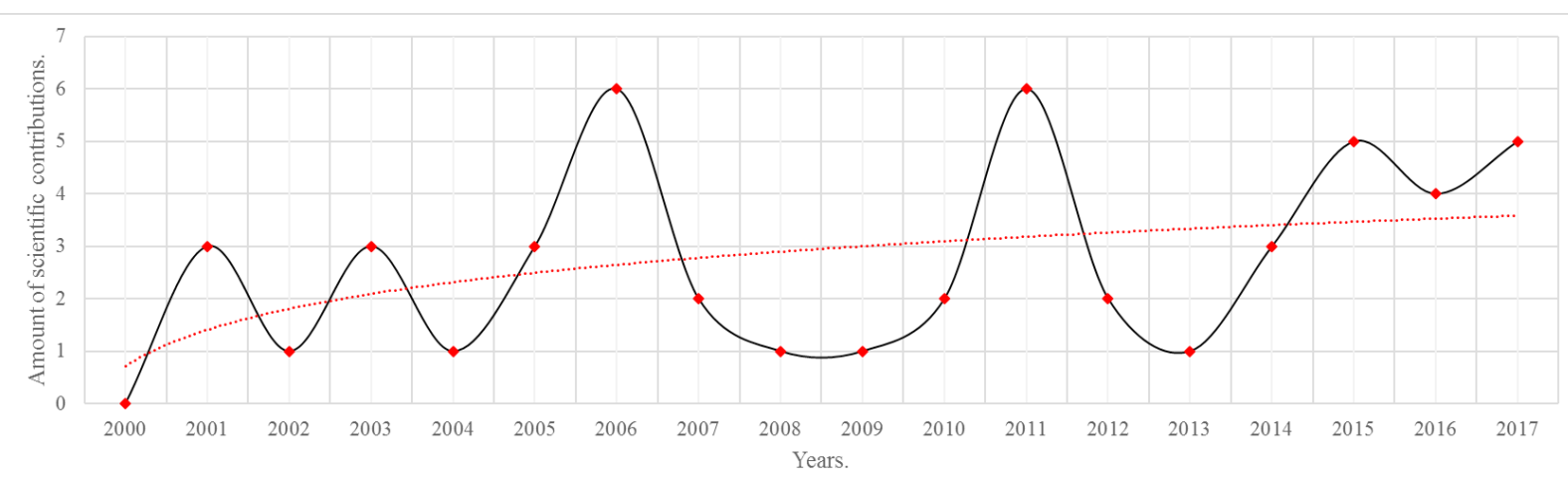

Fig. 2. Number of scientific publications on night ventilation from 2000 to 2017 registered in Scopus.

From an economic and technological perspective, nations see in night air conditioning by ventilation with outside air a timely and effective energy strategy to respond to the energetic demands of buildings. For instance, the amount of scientific production found in the search suggest that the United Kingdom, the United States of America and China are higly interested in this topic (Fig. 3). 


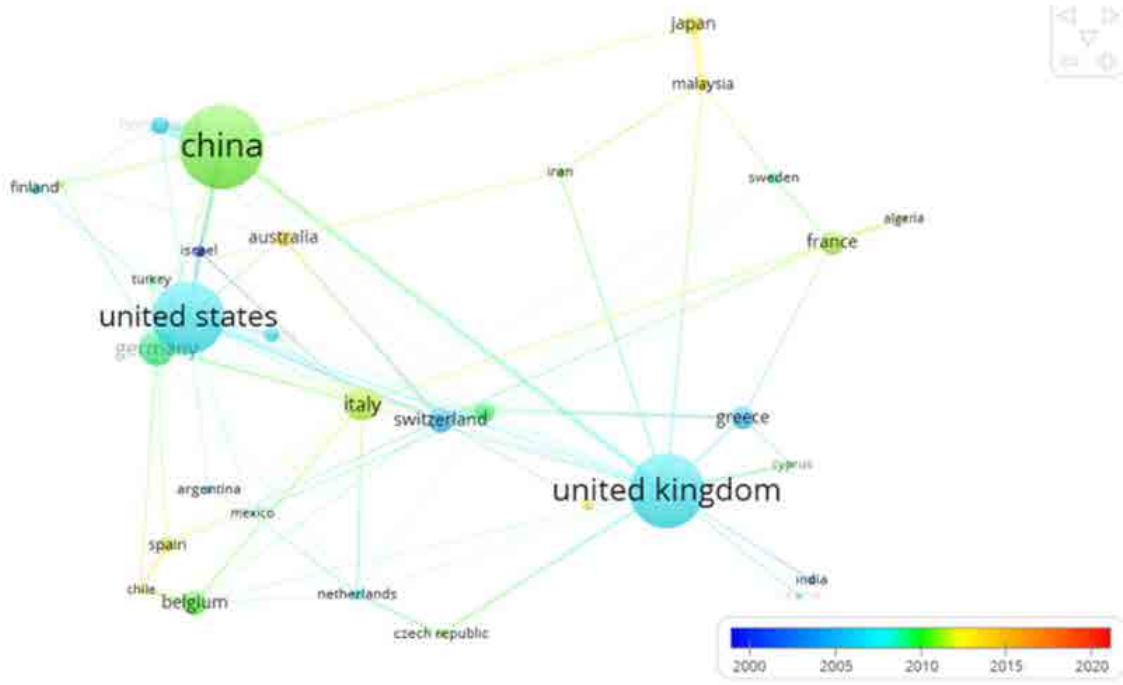

Fig. 3. Network of scientific research association in nocturnal ventilation of buildings, by nation. The color scale represents the years.

Night ventilation has been investigated and/or implemented from different approaches. Fig. 4 provides the distribution of scientific contributions published by different research areas.

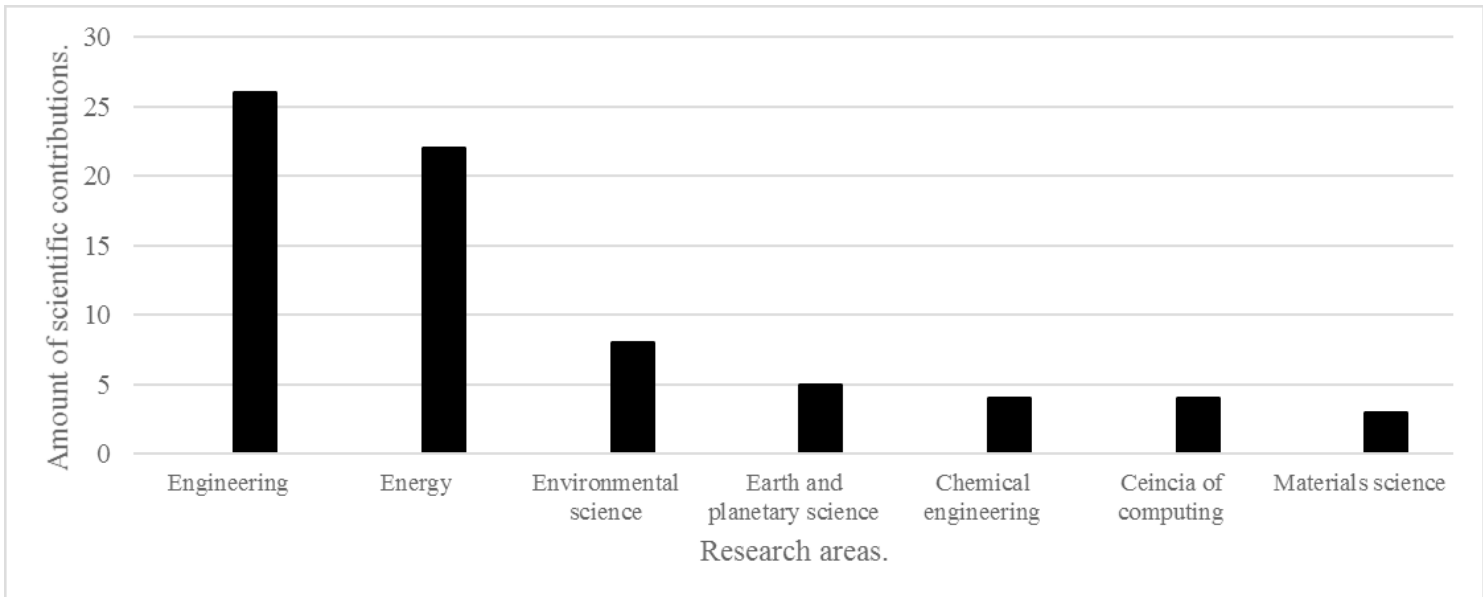

Fig. 4. Research areas in which air conditioning of buildings is developed using night ventilation.

The map of terms shown in Fig. 5 shows the relationship and the co-occurrence of keywords that identify the contours of investigations about nocturnal ventilation of buildings. The dimension of the spheres indicates the intensity of occurrence of the term, and the lines highlight their relationships. 


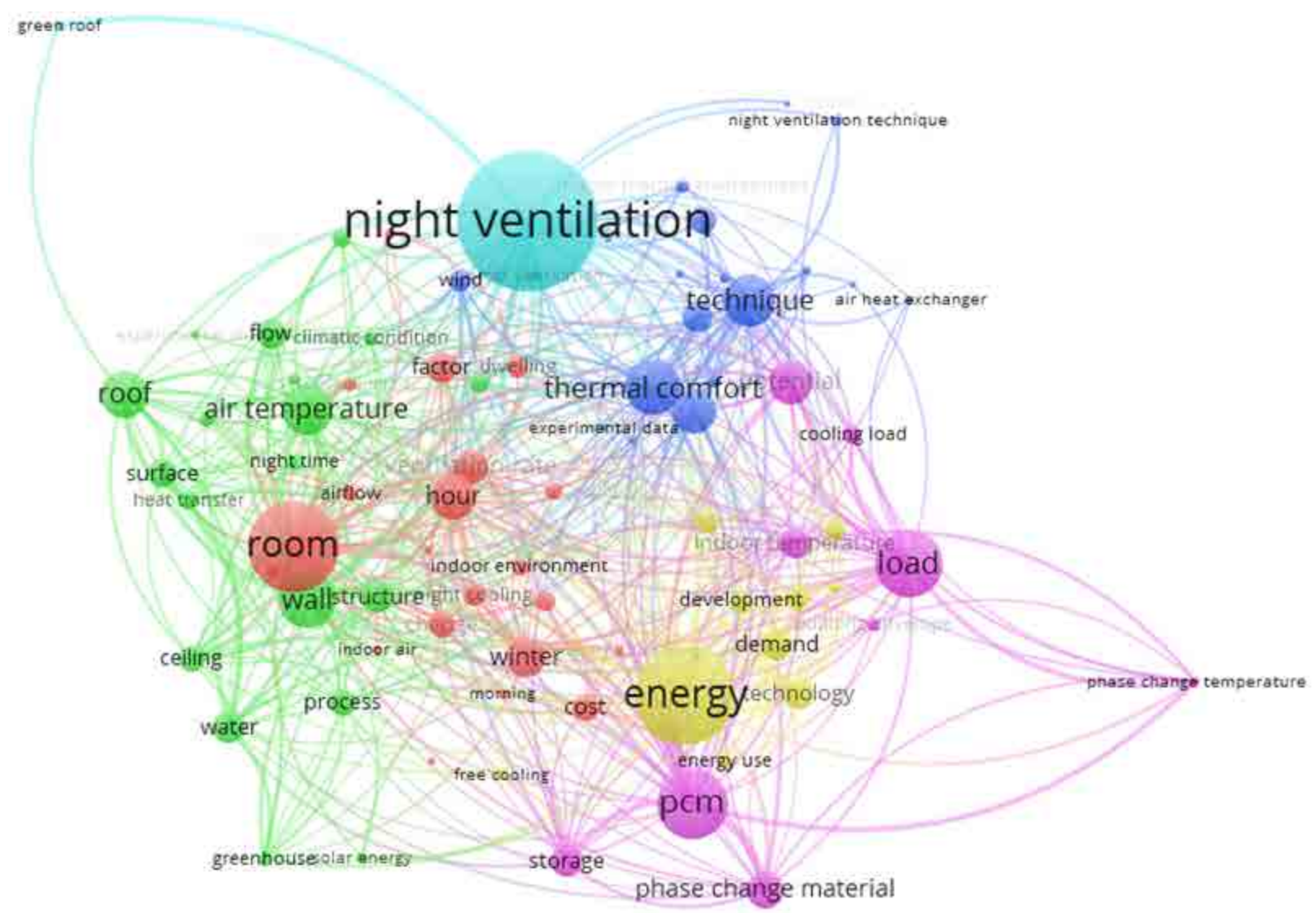

Fig. 5. Network showing the correlation of terms and their intensity of occurrence in studies on natural and mechanical ventilation of buildings.

Table 1 shows chronologically the studies that highlight the characteristics, innovations and trends in night ventilation of buildings. The last column from right to left shows the contributions' index $\mathrm{h}$; this index, proposed by Jorge Hirsch from the University of California, measures the quality of a contribution, based on the number of times it has been cited $[13,14]$. 


\section{Table 1}

RECENT STUDIES ON NIGHT VENTILATION AS A COOLING STRATEGY FOR BUILDINGS

\begin{tabular}{|c|c|c|c|c|c|}
\hline $\begin{array}{c}\text { General characteristic } \\
\text { of the investigation }\end{array}$ & Tools used & $\begin{array}{c}\text { Region or environmental } \\
\text { conditions }\end{array}$ & Objectives and main results & Reference & \begin{tabular}{|c|} 
Index \\
h
\end{tabular} \\
\hline $\begin{array}{l}\text { Experimental study } \\
\text { (outdoors) } \\
\text { supervision) }\end{array}$ & $\begin{array}{l}\text { Protected sensors to measure the } \\
\text { air temperature in guns. Three axis } \\
\text { anemometers to measure wind } \\
\text { speed and direction. }\end{array}$ & Athens, Greece & $\begin{array}{l}\text { Demonstrate and quantify the energy } \\
\text { benefits of night ventilation compared } \\
\text { to using conventional air conditioning } \\
\text { systems; through measurements in ten } \\
\text { cannons of the city of Athens. }\end{array}$ & {$[15]$} & 79 \\
\hline Simulation study & $\begin{array}{l}\text { A specific simulation tool developed } \\
\text { to analyze the energy performance } \\
\text { of office buildings. }\end{array}$ & London, United Kingdom & $\begin{array}{l}\text { The authors researched cooling by night } \\
\text { ventilation, both for urban and rural } \\
\text { environments in London. The results } \\
\text { showed critic points in the city areas, due } \\
\text { to the heat island effect. }\end{array}$ & {$[16]$} & 156 \\
\hline Theoretical study & $\begin{array}{l}\text { An extensive data set to map the } \\
\text { climatic conditions of the Iberian } \\
\text { Peninsula }\end{array}$ & Iberian Peninsula & $\begin{array}{l}\text { Evaluation of the night cooling capacities } \\
\text { through ventilation and evaporative } \\
\text { cooling, considering the climate of } \\
\text { the Iberian Peninsula. The authors } \\
\text { introduced a parameter called climate } \\
\text { cooling potential. }\end{array}$ & {$[17]$} & 6 \\
\hline Theoretical study & $\begin{array}{l}\text { Precise correlations } \\
\text { transferred for heat } \\
\text { implemented by in } \\
\text { (TRNSYS 16, 2016) }\end{array}$ & $\begin{array}{l}\text { General environmental } \\
\text { conditions }\end{array}$ & $\begin{array}{l}\text { Based on experimentation, the authors } \\
\text { evidenced the need and importance } \\
\text { of conducting predictive analyses of } \\
\text { the thermal behavior of buildings to } \\
\text { manage their nocturnal air conditioning } \\
\text { processes. }\end{array}$ & {$[18]$} & 18 \\
\hline Theoretical study & $\begin{array}{l}\text { New methodology based on } \\
\text { coupling several numerical tools } \\
(\text { e.g., MATLAB (2010) and Ansys } \\
\text { Fluent (2005)). }\end{array}$ & $\begin{array}{l}\text { General environmental } \\
\text { conditions }\end{array}$ & $\begin{array}{l}\text { Model that provides data processing in } \\
\text { a Computational Fluid Dynamics (CFD) } \\
\text { program, which allows optimizing night } \\
\text { cooling, considering all parameters, such } \\
\text { as thermal masses and their positions, } \\
\text { and the type of ventilation. }\end{array}$ & {$[19]$} & 10 \\
\hline Experimental study & Test room in Aalborg & $\begin{array}{l}\text { General environmental } \\
\text { conditions }\end{array}$ & $\begin{array}{l}\text { Simulations of the thermal energy } \\
\text { performance of a building are not } \\
\text { precise when evaluating heat transfered } \\
\text { by convection, under the operation of } \\
\text { night cooling. Therefore, new models } \\
\text { are necessary to evaluate the correct } \\
\text { coefficients of heat transferred by } \\
\text { convection, which are provided by } \\
\text { considering both mixed ventilation and } \\
\text { displacement mode. }\end{array}$ & {$[20]$} & 11 \\
\hline Numerical study & Two-dimensional DFC simulations & $\begin{array}{l}\text { General environmental } \\
\text { conditions }\end{array}$ & $\begin{array}{l}\text { The authors investigated eight } \\
\text { parameters affecting the performance } \\
\text { of nocturnal ventilation: discretization } \\
\text { grid, close wall treatment, simulation } \\
\text { time step, turbulence model, conjugate } \\
\text { heat transfer, radiation, and positions } \\
\text { and geometry of the entrance and exit } \\
\text { openings. }\end{array}$ & {$[21]$} & 10 \\
\hline Numerical simulation & $\begin{array}{l}\text { Transitory energy simulations } \\
\text { of an office building through } \\
\text { DesignBuilder } 2013\end{array}$ & Adelaide (South Australia) & $\begin{array}{l}\text { This research gave less interest to the } \\
\text { position of the thermal mass of the } \\
\text { installation. }\end{array}$ & {$[22]$} & 5 \\
\hline Numerical simulation & $\begin{array}{l}\text { Numerical simulation using the } \\
\text { IDA-ICE simulation tool, indoor } \\
\text { climate and energy }\end{array}$ & Solstad (Norway) & $\begin{array}{l}\text { This study aimed at finding the capacity } \\
\text { of night cooling that allows improving } \\
\text { the thermal performance of a Norwegian } \\
\text { children's facility in cold climates. } \\
\text { Positive effects were found in almost all } \\
\text { periods of the year. }\end{array}$ & {$[23]$} & 2 \\
\hline
\end{tabular}




\begin{tabular}{|c|c|c|c|c|c|}
\hline $\begin{array}{c}\text { General characteristic } \\
\text { of the investigation }\end{array}$ & Tools used & $\begin{array}{c}\text { Region or environmental } \\
\text { conditions }\end{array}$ & Objectives and main results & Reference & $\begin{array}{c}\text { Index } \\
h\end{array}$ \\
\hline $\begin{array}{l}\text { Numerical simulation } \\
\text { with validation }\end{array}$ & \begin{tabular}{|lr} 
Predictive control model \\
implemented in energy simulations \\
with TRNSYS (TRNSYS & $16,2016)$
\end{tabular} & $\begin{array}{l}\text { Ljubljana (Slovenia) } \\
\text { Berlin (Germany), } \\
\text { Stockholm (Sweden), } \\
\text { Rome (Italy), Madrid } \\
\text { (Spain) }\end{array}$ & $\begin{array}{l}\text { G-MPWC, a new predictive control } \\
\text { model, was developed for managing and } \\
\text { evaluating nocturnal ventilation, based } \\
\text { on the weather forecast, the flow rate, } \\
\text { the coefficient of performance and the } \\
\text { predicted interior temperatures. }\end{array}$ & {$[24]$} & 6 \\
\hline $\begin{array}{l}\text { Numerical study } \\
\text { with validation (in a } \\
\text { different location) }\end{array}$ & \begin{tabular}{|lll} 
Numerical & simulations & in \\
EnergyPlus (US Department & of \\
Energy, 2012) & & \\
\end{tabular} & Yazd (Iran) & $\begin{array}{l}\text { A light construction, equipped with an } \\
\text { air conditioning system, was investigated } \\
\text { using mechanical ventilation at night, to } \\
\text { discharge the adopted PCM materials } \\
\text { to increase the thermal capacity (latent } \\
\text { heat storage) of the building. The purge } \\
\text { air had a great impact in terms of cooling } \\
\text { potential. }\end{array}$ & {$[25]$} & 17 \\
\hline Numerical simulation & \begin{tabular}{|lrr} 
Energy $\quad$ simulations & in \\
DesignBuilder, $\quad 2013$ & and \\
EnergyPlus & 2012 programs.
\end{tabular} & Mediterranean climates & $\begin{array}{l}\text { Locations in the Mediterranean ( } 50 \\
\text { climatic areas) were investigated by } \\
\text { varying the envelope composition of the } \\
\text { modeled office building and taking into } \\
\text { account two models of thermal comfort. } \\
\text { The cooling potential of mechanical } \\
\text { ventilation was evaluated, with and } \\
\text { without natural ventilation. }\end{array}$ & {$[26]$} & 19 \\
\hline Theoretical study & $\begin{array}{l}\text { A new optimized scheme } \\
\text { (mathematical modeling) to improve } \\
\text { the performance of night cooling }\end{array}$ & $\begin{array}{l}\text { Four different cities in the } \\
\text { USA: Houston, Memphis, } \\
\text { Albuquerque and Boise }\end{array}$ & $\begin{array}{l}\text { An improvement of an air conditioning } \\
\text { system with Variable Air Ventilation } \\
\text { (VAV) was proposed, integrating an } \\
\text { optimal control of natural ventilation } \\
\text { and the activation of air conditioning. } \\
\text { The optimized control provided a really } \\
\text { significant energy saving compared to the } \\
\text { base cases (with a system without natural } \\
\text { ventilation, with fixed operating hours). }\end{array}$ & {$[27]$} & 5 \\
\hline Theoretical study & $\begin{array}{l}\text { Numerical study using BSim, } \\
\text { an energy tool from the Danish } \\
\text { Building Research Institute }\end{array}$ & Copenhagen, Denmark & $\begin{array}{l}\text { A new and integrated theoretical system } \\
\text { for an office building in Copenhagen was } \\
\text { propose. It combines natural ventilation, } \\
\text { activation of the thermal mass of the } \\
\text { building and diffuse ventilation of the } \\
\text { roof, to provide the best cooling of the } \\
\text { highly insulated building. }\end{array}$ & {$[28]$} & 15 \\
\hline
\end{tabular}

\section{Discussion}

Geros et al. [15] evidenced the negative effects of urban canyons in terms of reducing the cooling potential of nocturnal ventilation. They conducted experiments and measured wind speed and air temperature, and found that within the urban canyons, the elimination heat at night from buildings out to the environment, both by convection and radiation, decreased. In other words, if the specific location is not considered, and the calculations are done simply on the basis of general meteorological data, the cooling potential of nocturnal ventilation can be overestimated. This observation is valid both for nocturnal ventilation and for conventional air conditioning, due to the higher surface temperatures of urban canyons and the lower air speed, compared to open spaces.
In order to overcome the problem of urban morphology, which can decrease the local achievable cooling benefits of nocturnal ventilation, Kolokotroni et al. [16] proposed, for cooling office buildings at night, to apply ventilation at heights greater than 9 $\mathrm{m}$. In this investigation, the authors used a computer tool that allowed the reliable simulation of the air flow in the urban environment. In the case of the climate of London, the simulations revealed that in rural conditions the need for cooling is lower than in the city, and that on typical summer days, the optimization of passive cooling strategies can avoid active cooling [16].

A new concept of climate cooling potential was recently introduced by Campaniço et al. [17] who analyzed, for the climatic area of the Iberian Peninsula, a new methodology to determine the potential savings in cooling of buildings due to the adoption of 
passive strategies, such as direct night ventilation and evaporative cooling. Campaniço and collaborators proposed a method to estimate, regardless of the peculiarities of the building and without resorting to energy simulations, the cooling potential of a building according to the climatic conditions given by its location. Particularly, they used a large set of climatic data, through an extensive mapping of the Iberian Peninsula, with a resolution of nine kilometers and an observation period of 19 years. They found that the free cooling potential of both natural ventilation and evaporative cooling was much greater in the northern zone of the peninsula than in the southern zone; and that cooling by evaporation was more effective, although it was less evident for coastal regions. This study confirmed that direct ventilation has a more significant cooling potential in regions with high differences in air temperature between day and night hours.

Goethals et al. [18] focused on the convective heat transfer coefficients inside the buildings. They indicated that both the effectiveness of night cooling and the reliable prediction of thermal behavior are strongly related to the model adopted for the convection algorithm. A reliable prediction of heat transfer by convection requires an approach based on computational simulations of fluid dynamics, which are much more demanding from a computational point of view than the simulations of variations of energy flow as a function of time. The authors highlighted these aspects, evidencing that, when night ventilation is designed, it is necessary to precise a construction model through computational simulations of fluid dynamics or, alternatively, to conduct experiments that provide reliable values for convection heat transfer. Posteriorly and taking into account these results, Goethals et al. [19] provided a sensitivity study to determine the connection between the nocturnal ventilation potential and the interior space design. They implemented a model based on the automated sampling of input data and computational simulations of fluid dynamics, by coupling several computational tools, such as MATLAB 2010 and Ansys Fluent 2005. This study was conducted in office buildings and provided the optimization of the ventilation systems; in particular, Goethals et al. [19] found that the parameters that strongly influence the cooling potential of night ventilation were the thermal mass and its position, as well as the choice of lateral ventilation strategies.
Le Dréau et al. [20] analyzed the efficiency of heat transfer in the exploitation of nocturnal ventilation. In this publication, several softwares available for simulation of real estate energy behavior were analyzed, as well as their capability to predict the heat exchange by convection. Through experimentation, they derived reliable convection heat transfer coefficients, considering ventilation according to the mixed and displacement models. In comparison with the existing correlations, Le Dréau's experiments, conducted in the large-scale test room at the University of Aalborg in Denmark, showed that the main discrepancies were verified for mixed ventilation and for the room's space near the entrances. Furthermore, better correspondences were found in the case of displacement ventilation if the surfaces were not directly involved in the movement of air due to the proximity to the entrance. Le Dréau and collaborators concluded that energy simulation tools fail predicting heat fluxes by convection if the local heat transfer coefficients are not determined properly; therefore, despite difficulties, improving these tools according to criticality is necessary because of their effects on thermal comfort.

The precision problem of the thermo-energy simulations when evaluating the heat exchange by convection was also evidenced by Leenknegt et al. [21]. In this research, a sensitivity study was carried out, using two-dimensional computational simulations of fluid dynamics to identify the influence of eight parameters. These parameters were grouped into two categories: in the first one, the influence of the modeling options (e.g., the discretization grid, the fluid treatment near the wall, the simulation time, and the adopted turbulence model) was evaluated; and in the second one, the sensitivity study, the impacts of the model simplification (conjugate heat transfer, radiation, positions and geometry of the entry and exit areas) were investigated. Leenknegt and collaborators found that both the convective heat transfer coefficient and the convection surface heat flux vary significantly over time and, therefore, the transient nature of the phenomenon must be carefully considered during the design of strategies and technologies of night ventilation.

For the climate of Adelaide in Australia, and taking into account several configurations of facades and the location of the thermal mass, Roach et al. [22] highlighted the integration of night ventilation with air conditioning systems for an office building. They 
conducted computer simulations with the EnergyPlus 2012 software and found that the position of the thermal mass was not significant, while the amount of ventilation air was of great importance. In particular, they found that the energy needed for cooling off the building decreases sharply if the air flow rates increase; this result was corroborated by [29].

Strong thermal insulation can degrade the summer performance of buildings [22]. This issue was addressed by several athors [29-31]. Nocturnal ventilation in summer can contribute to unload the thermal masses of the building, limiting the flows of conduction heat towards the external surroundings, due to the high thermal resistance of the building's envelope. Alonso et al. [23] investigated the same problems in a contribution dedicated entirely to the role of night cooling in improving the thermal performance of buildings with high thermal insulation. They conducted air conditioning simulations for a building intended for early childhood education in Solstad (Norway) by combining mechanical cooling and night ventilation, and using the IDA ICE transient energy analysis software. Their results emphasize the efficiency of night cooling in reducing the interior temperature, and therefore, decreasing the need for active cooling. Night cooling, mainly with mechanical support, requires careful control. In fact, if it is considered as a low-energy cooling strategy, the electric motors of the fans and extractors represent a consumption, so that excessive amounts of air flow can provide unwanted energy consumption.

To improve the performance of night cooling by mechanical ventilation, Vidrih et al. [24] proposed a predictive control model based on weather forecasts in real-time and short-term response of the building's air conditioning system. The generalized model-based predictive weather control (G-MPWC) algorithm, which can manage night ventilation throughout the summer, was developed to provide information on possible free cooling, air flow terms, coefficient of performance and expected indoor temperatures. The G-MPWC, implemented in the TRNSYS 16 software, was used in the thermo-energy analysis of various types of buildings. Simulations were proposed for five locations: Ljubljana, Berlin, Stockholm, Rome and Madrid. The reliability of the method was verified by comparing simulations and measurements in an office building monitored for twelve days. In terms of gaps between the model and the measurements, the results validated the predictions with reference to indoor and outdoor air temperatures, air flow rates and the coefficient of performance, so the authors concluded that implementing the algorithm in control units of mechanical ventilation systems is reliable.

Solgi et al. [25] studied the improvement of thermal performance in office buildings located in Yazd, Iran, by adopting mechanical night ventilation, to evacuate the thermal load of the phase change materials (PCM) used to increase the thermal capacity of the building envelope. They based their research on numerical simulations, conducted with EnergyPlus 2012, by adopting the energy balance algorithm based on the finite difference of thermal conduction. The authors evaluated an optimal air flow for the nocturnal periods in this region, and found that a further increase in the rates of air change increases the energy consumption of the fans without improving the thermal efficiency of the discharge period of the PCM.

Chiesa and Grosso [26] used DesignBuilder 2013 and EnergyPlus 2012 to evaluate the potential of natural controlled ventilation as a cooling strategy for several Mediterranean climates. The simulations were made by varying the composition of the building envelope (office building, $365 \mathrm{~m}^{2}$, two floors) and including two different controls of the interior conditions. In particular, thermal comfort was studied according to a traditional approach in which it is achieved at an indoor temperature lower than $26^{\circ} \mathrm{C}$ and considering the adaptive approach of the EN 15251 [32] and ASHRAE 55-2103 [33] standards. Besides varying the thermal conductivity of the building envelope, the type of ventilation was also varied. In all the climates investigated, the calculated cooling potential was significant.

Finally, Zhang et al. [27] and Yu et al. [28] sought to optimize building energy and thermal performance by implementing various passive and active strategies. In particular, Zhang and collaborators studied four different climates in the United States of America: Houston (hot), Memphis (warm), Albuquerque (mixed) and Boise (cold); they proposed a complete dynamic management for the integrated operation of passive cooling by natural ventilation and conventional refrigeration. The dynamic control needed a complex study to optimize the administration scheme, within a procedure based on the use of a general algebraic modeling system (GAMS). For the investigated building, which operated daily for $24 \mathrm{~h}$, the optimized control scheme, characterized by integrating natural 
ventilation and air conditioning, was compared with the benefits achieved with a volume system of conventional variable air, with or without a common program of natural ventilation. According to the comparisons in different climatic conditions, the dynamic optimization control allows significant energy savings, in the range of 23 to $49 \%$.

On the other hand, Yu et al. [28] reviewed the literature extensively, focusing on passive cooling for highly insulated buildings. The authors combined, in a novel integrated system, three passive cooling strategies: natural ventilation, activation of the thermal mass of the building and diffuse ventilation of the roof. They developed various modes of operation and carried out simulations with BSim, a complete tool developed by the Danish Building Research Institute, to evaluate the energy performance of buildings. Yu and collaborators investigated an office room and run the simulations under Copenhagen climate conditions, finding significant benefits at all stations. Their results, in terms of primary energy, were calculated for different internal loads, and they found benefits related to the reduction of active cooling, with energy savings up to $50 \%$. With regard to extremely hot periods, natural ventilation was not enough. The authors evidenced the need for a careful design, mainly to adequately evaluate the relevant external air flow speed.

\section{Conclusions}

This research showed a growing trend in the contributions related to night ventilation of buildings, which can be interpreted as an increase in interest in this energy practice within the international scientific community. In this sense, it is possible to emphasize that the nations at the forefront in the study and implementation of this energy strategy are China, the United Kingdom and the United States of America.

If the specific location is not considered, and calculations are done simply on the basis of general meteorological data from the area, the cooling potential of night ventilation can be overestimated.

Direct ventilation has a more significant cooling potential in regions characterized by a high difference between day and night air temperatures.
The effectiveness of night cooling and the reliable prediction of thermal behavior are strongly related to the model adopted for the convection algorithm.

A reliable prediction of heat transfer by convection requires an approach based on computational simulations of fluid dynamics, which are much more demanding from the computational point of view, as opposed to simulations of energy flow variations depending on the weather.

A precise construction model, through computational simulations of fluid dynamics or real experiments that provide reliable values of convection heat transfer, is necessary for a correct design and operation of night ventilation systems.

Thermal mass, mainly its position, and the choice of lateral ventilation strategies are the parameters that strongly influence the cooling potential of night ventilation.

The coefficient of convective heat transfer and the convection surface heat flux vary significantly over time, and therefore, the transient nature of the phenomenon should be carefully considered during the design of night ventilation strategies and technologies.

In most investigations the position of the thermal mass is not significant, while the amount of ventilation air is of great importance. In particular, the energy demand for cooling off a building decreases sharply if the air flow rates increase.

\section{REFERENCES}

[1] M. Boulic, et al., "Increasing the ventilation rate and temperature in New Zealand classrooms using a solar roof collector," in Central Europe Towards Sustainable Building 2016: Innovations for Sustainable Future, 2016, pp. 1559-1566: Grada Publishing.

[2] D. Bravo Hidalgo, "Climatización solar de edificaciones" Centro Azúcar, vol. 42, pp. 72-82, 2015.

[3] A. I. AbdelAzim, A. M. Ibrahim, and E. M. AboulZahab, "Development of an energy efficiency rating system for existing buildings using Analytic Hierarchy Process - The case of Egypt," Renewable and Sustainable Energy Reviews, Review vol. 71, pp. 414-425, May. 2017. DOI: https://doi.org/10.1016/j. rser.2016.12.071. 
[4] G. Y. Yun, and K. Song, "Development of an automatic calibration method of a VRF energy model for the design of energy efficient buildings," Energy and Buildings, Article vol. 135, pp. 156-165, Jan. 2017. DOI: https://doi. org/10.1016/j.enbuild.2016.11.060.

[5] H. Yi, R. S. Srinivasan, W. W. Braham, and D. R. Tilley, "An ecological understanding of net-zero energy building: Evaluation of sustainability based on emergy theory," Journal of Cleaner Production, vol. 143, pp. 654-671, Feb. 2017. DOI: https://doi.org/10.1016/j. jclepro.2016.12.059.

[6] M. Kostka, and M. Szulgowska-Zgrzywa, "Change-over natural and mechanical ventilation system energy consumption in single-family buildings," in International Conference on Advances in Energy Systems and Environmental Engineering, 2017. DOI: https:// doi.org/10.1051/e3sconf/20172200086.

[7] M. J. Alonso, H. M. Mathisen, and R. Collins, "Ventilative cooling as a solution for highly insulated buildings in cold climate," in 6th International Building Physics Conference, 2015, vol. 78, pp. 3013-3018. DOI: https://doi. org/10.1016/j.egypro.2015.11.707.

[8] D. E. Kalz, and J. Pfafferott, "Comparative evaluation of natural ventilated and mechanical cooled non-residential buildings in Germany: Thermal comfort in summer," in Conference on Adapting to Change: New Thinking on Comfort, Windsor, 2010.

[9] P. Blecich, M. Franković, and Ž. Kristl, "Energy retrofit of the Krsan Castle: From sustainable to responsible design - A case study," Energy and Buildings, vol. 122, pp. 23-33, Jun. 2016. DOI: https://doi.org/10.1016/j.enbuild.2016.04.011.

[10] A. I. Ibiyeye, F. Z. J. Mohd, and S. Zalina, "Natural ventilation provisions in terracedhouse designs in hot-humid climates: Case of Putrajaya, Malaysia," Pertanika Journal of Social Sciences and Humanities, vol. 23(4), pp. 885-904, 2015.

[11] A. R. Rempel, and S. J. Remington, "Optimization of passive cooling control thresholds with GenOpt and EnergyPlus," in 2015 Symposium on Simulation for Architecture and Urban Design, SimAUD 2015, Part of the 2015 Spring Simulation Multi-Conference, SpringSim 2015, 2015, vol. 47, pp. 103-110.

[12] A. M. Omer, "Principle of low energy building design: Heating, ventilation and air conditioning," in Advances in Energy Research, vol. 20: Nova Science Publishers, 2014, pp. 57103.

[13] M. Raheel, S. Ayaz, and M. T. Afzal, "Evaluation of h-index, its variants and extensions based on publication age $\&$ citation intensity in civil engineering," Scientometrics, vol. 114(3), pp. 1107-1127, Mar. 2018. DOI: https://doi. org/10.1007/s11192-017-2633-2.

[14] J. A. Teixeira da Silva, and J. Dobránszki, "Multiple versions of the h-index: cautionary use for formal academic purposes," Scientometrics, Article in Press, pp. 1-7, 2018.

[15] V. Geros, M. Santamouris, S. Karatasou, A. Tsangrassoulis, and N. Papanikolaou, "On the cooling potential of night ventilation techniques in the urban environment," Energy and Buildings, vol. 37(3), pp. 243-257, Mar. 2005. DOI: https:// doi.org/10.1016/j.enbuild.2004.06.024.

[16] M. Kolokotroni, I. Giannitsaris, and R. Watkins, "The effect of the London urban heat island on building summer cooling demand and night ventilation strategies," Solar Energy, vol. 80(4), pp. 383-392, Apr. 2006. DOI: https://doi. org/10.1016/j.solener.2005.03.010.

[17] H. Campaniço, P. M. M. Soares, P. Hollmuller, and R. M. Cardoso, "Climatic cooling potential and building cooling demand savings: High resolution spatiotemporal analysis of direct ventilation and evaporative cooling for the Iberian Peninsula," Renewable Energy, vol. 85(Supplement C), pp. 766-776, Jan. 2016. DOI: https://doi.org/10.1016/j.renene.2015.07.038.

[18] K. Goethals, H. Breesch, and A. Janssens, "Sensitivity analysis of predicted night cooling performance to internal convective heat transfer modelling," Energy and Buildings, vol. 43(9), pp. 2429-2441,Sep. 2011. DOI: https://doi. org/10.1016/j.enbuild.2011.05.033.

[19] K. Goethals, I. Couckuyt, T. Dhaene, and A. Janssens, "Sensitivity of night cooling performance to room/system design: Surrogate models based on CFD," Building and Environment, vol. 58(Supplement C), pp. 2336, Dec. 2012. DOI: https://doi.org/10.1016/j. buildenv.2012.06.015.

[20] J. Le Dréau, P. Heiselberg, and R. L. Jensen, "Experimental investigation of convective heat transfer during night cooling with different ventilation systems and surface emissivities," Energy and Buildings, vol. 61, pp. 308-317, 
Jun. 2013. DOI: https://doi.org/10.1016/j. enbuild.2013.02.021.

[21] S. Leenknegt, R. Wagemakers, W. Bosschaerts, and D. Saelens, "Numerical sensitivity study of transient surface convection during night cooling," Energy and Buildings, vol. 53, pp. 8595, Oct. 2012. DOI: https://doi.org/10.1016/j. enbuild.2012.06.020.

[22] P. Roach, F. Bruno, and M. Belusko, "Modelling the cooling energy of night ventilation and economiser strategies on façade selection of commercial buildings," Energy and Buildings, vol. 66, pp. 562-570, Nov. 2013. DOI: https:// doi.org/10.1016/j.enbuild.2013.06.034.

[23] M. J. Alonso, H. M. Mathisen, and R. Collins, "Ventilative Cooling as a Solution for Highly Insulated Buildings in Cold Climate," Energy Procedia, vol. 78, pp. 3013-3018, Nov. 2015. DOI: https://doi.org/10.1016/j. egypro.2015.11.707.

[24] B. Vidrih, C.Arkar, and S. Medved, "Generalized model-based predictive weather control for the control of free cooling by enhanced night-time ventilation," Applied Energy, vol. 168, pp. 482492, Apr. 2016. DOI: https://doi.org/10.1016/j. apenergy.2016.01.109.

[25] E. Solgi, R. Fayaz, and B. M. Kari, "Cooling load reduction in office buildings of hot-arid climate, combining phase change materials and night purge ventilation," Renewable Energy, vol. 85, pp. 725-731, Jan. 2016. DOI: https:// doi.org/10.1016/j.renene.2015.07.028.

[26] G. Chiesa and M. Grosso, "Geo-climatic applicability of natural ventilative cooling in the Mediterranean area," Energy and Buildings, vol. 107, pp. 376-391, Nov. 2015. DOI: https:// doi.org/10.1016/j.enbuild.2015.08.043.

[27] R. Zhang, Y. Nie, K. P. Lam, and L. T. Biegler, "Dynamic optimization based integrated operation strategy design for passive cooling ventilation and active building air conditioning,"
Energy and Buildings, vol. 85, pp. 126-135, Dec. 2014. DOI: https://doi.org/10.1016/j. enbuild.2014.09.032.

[28] T. Yu, P. Heiselberg, B. Lei, M. Pomianowski, and C. Zhang, "A novel system solution for cooling and ventilation in office buildings: A review of applied technologies and a case study," Energy and Buildings, vol. 90, pp. 142155, Mar. 2015. DOI: https://doi.org/10.1016/j. enbuild.2014.12.057.

[29] F. Ascione, L. Bellia, P. Mazzei, and F. Minichiello, "Solar gain and building envelope: the surface factor," Building Research \& Information, vol. 38(2), pp. 187-205, Apr. 2010. DOI: https://doi. org/10.1080/09613210903529118.

[30] F. Ascione, N. Bianco, R. F. De Masi, F. de Rossi, C. De Stasio, and G. P. Vanoli, "Energy audit of health care facilities: Dynamic simulation of energy performances and energy-oriented refurbishment of system and equipment for microclimatic control," American Journal of Engineering and Applied Sciences, Article vol. 9(4), pp. 814-834, Apr. 2016. DOI: https://doi. org/10.3844/ajeassp.2016.814.834.

[31] F.Ascione, O. Böttcher, R. Kaltenbrunner, and G. P. Vanoli, "Methodology of the cost-optimality for improving the indoor thermal environment during the warm season. Presentation of the method and application to a new multi-storey building in Berlin," Applied Energy, vol. 185, pp. 1529-1541, Jan. 2017. DOI: https://doi. org/10.1016/j.apenergy.2015.10.169.

[32] B. EN, “15251: 2007," Indoor environmental input parameters for design and assessment of energy performance of buildings addressing indoor air quality, thermal environment, lighting and acoustics, 2007.

[33] A. Standard, "Standard 55-2010: "Thermal Environmental Conditions for Human Occupancy"; ASHRAE," Atlanta USA, 2010. 
